\title{
Fungal cellulases: production by solid-state cultivation in packed- bed bioreactor using solid agro-industrial by-products as substrates and application for hydrolysis of sugarcane bagasse
}

\section{Celulases fúngicas: produção por cultivo sólido em biorreator de leito empacotado usando resíduos sólidos agroindustriais como substratos e aplicação na hidrólise de bagaço de cana}

\author{
Priscila Aparecida Casciatori Frassatto ${ }^{1}$; Fernanda Perpétua Casciatori ${ }^{2}$; \\ João Cláudio Thoméo ${ }^{3}$; Eleni Gomes ${ }^{4}$; Maurício Boscolo ${ }^{4}$; Roberto da Silva ${ }^{4 *}$
}

\begin{abstract}
Highlights:
Agricultural waste were applied for cultivation of a cellulolytic fungal strain. Cellulases produced were applied for hydrolysis of sugarcane bagasse.

Experimental design helped to optimize enzymatic hydrolysis.

Sugarcane bagasse was pre-treated combining ozone, alkali and ultrasound.

High yields of conversion of cellulose into glucose were achieved.
\end{abstract}

\begin{abstract}
Cellulases are essential for the hydrolysis of lignocellulosic materials in the production of second generation ethanol. Solid-state cultivation is a process that provides high concentrations of enzymes that can be used in this hydrolysis. The objectives of this work were to produce cellulases by cultivating the fungus Myceliophthora thermophila I-1D3b in a packed bed bioreactor with sugarcane bagasse (SCB) and wheat bran (WB) as substrate and to evaluate the efficiency of the enzymatic extract in the hydrolysis of SCB in natura (BIN) and pretreated with ozone, alkali and ultrasound (BOU). The conditions for enzyme production in the bioreactor were SCB:WB at a ratio of 2.3:1 (w/w), $75 \%$ moisture content; $45^{\circ} \mathrm{C}$; aeration rate $240 \mathrm{~L} \mathrm{~h}^{-1}$ and $96 \mathrm{~h}$. The enzyme production was evaluated by endoglucanase, xylanase, filter paper (FPU) and $\beta$-glycosidase activities. For the application of the enzymes, a central composed response surface design with 5 repetitions of the central point was used, taking enzyme volume and hydrolysis time as factors. Such cultivation yielded the following enzymatic activities: $723 \mathrm{U} \mathrm{gss}^{-1}$ of endoglucanases, $2024 \mathrm{U} \mathrm{gss}^{-1}$ of xylanase, $12.6 \mathrm{U} \mathrm{gss}^{-1}$ of FPU and $41 \mathrm{U} \mathrm{gss}^{-1}$ of $\beta$-glucosidase. The results of the application tests indicated the best conditions as $7.0 \mathrm{~mL}$ of the enzyme extract (4.2 FPU) and 6 hours for BIN and BOU. The best cellulose-glucose conversions were obtained for BOU, reaching $32.1 \%$ at $65{ }^{\circ} \mathrm{C}$. In conclusion, the enzyme production in the packed bed bioreactor was efficient and $\mathrm{BOU}$ pretreatment improved the hydrolysis of biomass, increasing the efficiency of conversion of cellulose to glucose.
\end{abstract}

Key words: Bioethanol. Cellulases. Pretreatment. Saccharification. Solid cultivation.

\footnotetext{
${ }^{1}$ Discente do Curso de Doutorado do Programa de Pós-Graduação em Química, Instituto de Biociências, Letras e Ciências Exatas, IBILCE, Universidade Estadual Paulista, UNESP, São José do Rio Preto, SP, Brasil. E-mail: pricasciatori@yahoo.com.br

2 Prof ${ }^{a}$. Dr ${ }^{\mathrm{a}}$, Universidade Federal de São Carlos, UFSCar, São Carlos, SP, Brasil. E-mail: fernanda.casciatori@ufscar.br

3 Prof. Dr., Instituto de Biociências, Letras e Ciências Exatas, IBILCE, UNESP, São José do Rio Preto, SP, Brasil. E-mail: joao. thomeo@unesp.br

4 Profs. Drs., Instituto de Biociências, Letras e Ciências Exatas, IBILCE, UNESP, São José do Rio Preto, SP, Brasil. E-mail: eleni. gomes@unesp.br; mauricio.boscolo@unesp.br; roberto.silva@unesp.br
}

* Author for correspondence 


\section{Resumo}

Celulases são essenciais para a hidrólise de materiais lignocelulósicos visando à produção de etanol de segunda geração. O cultivo em estado sólido é um processo que proporciona altas concentrações de enzimas que podem ser aplicadas nessa hidrólise. O objetivo deste trabalho foi produzir celulases pelo fungo Myceliophthora thermophila I-1D3b em biorreator de leito empacotado com bagaço de cana (BC) e farelo de trigo (FT) como substrato e avaliar a eficiência deste extrato enzimático na hidrólise de bagaço de cana in natura (BIN) e pré-tratado com ozônio, álcali e ultrassom (BOU). As condições para produção de enzimas no biorreator foram BC:FT numa proporção de 2,3:1 (m/m); 75 \% de umidade em base úmida; $45^{\circ} \mathrm{C}$; taxa de aeração $240 \mathrm{~L} \mathrm{~h}^{-1}$ e $96 \mathrm{~h}$. A produção de enzimas foi avaliada pelas atividades de endoglucanase, xilanase, papel de filtro (FPU) e $\beta$-glicosidase. Para a aplicação das enzimas, foi utilizado um planejamento de superfície de resposta central composto com 5 repetições do ponto central, tendo como fatores o volume de extrato enzimático e o tempo de hidrólise. Esse cultivo produziu as seguintes atividades enzimáticas: $723 \mathrm{U} \mathrm{gss}^{-1}$ de endoglucanases, $2024 \mathrm{U} \mathrm{gss}^{-1} \mathrm{de}$ xilanase, 12,6 $\mathrm{U} \mathrm{gss}^{-1}$ de FPU e $41 \mathrm{U} \mathrm{gss}^{-1}$ de $\beta$-glucosidase. Os resultados da aplicação dessas enzimas na hidrólise indicaram como ótimos 7,0 $\mathrm{mL}$ de extrato enzimático (4,2 FPU) e 6 horas para BIN e BOU. As melhores conversões de celulose-glicose foram obtidas para a BOU, atingindo $32,1 \%$ a $65^{\circ} \mathrm{C}$. Em conclusão, a produção de enzimas no biorreator de leito compactado foi eficiente e o pré-tratamento BOU melhorou a hidrólise da biomassa, aumentando a eficiência de conversão de celulose em glicose.

Palavras-chave: Bioetanol. Celulases. Pré-tratamento. Sacarificação. Cultivo sólido.

\section{Introduction}

In the context of the technological development of renewable energy sources, cellulolytic enzymes have attracted the attention of the scientific and industrial community, in view of their application in the hydrolysis of lignocellulosic materials to produce cellulosic ethanol, also called second generation ethanol $(2 \mathrm{G})$ or bioethanol.

In Brazil, an abundant raw material for conversion to $2 \mathrm{G}$ is sugarcane bagasse (SCB), a residue from the production of first generation ethanol $(1 \mathrm{G})$. However, $2 \mathrm{G}$ production is limited by the recalcitrance of SCB. The sugarcane cell wall is composed of cellulose fibers embedded in a matrix of interconnected hemicelluloses and lignin, which hinders the action of hydrolytic enzymes to obtain fermentable sugars. Only by destroying this recalcitrant mesh and removing the lignin can the enzymes access the sugar polymers (Florencio, Badino, \& Farinas, 2017).

Therefore, chemical, physical and/or biological pretreatments have been proposed in order to facilitate the access of cellulases to the substrate producing higher yields from the hydrolysis, i.e. increasing the amount of fermentable sugars (Baruah et al., 2018). Ozone, a powerful oxidative agent, can be used as a chemical pretreatment of lignocellulosic biomass in an advanced oxidative process called ozonolysis (Canilha et al., 2012). The main effect of this pretreatment is the removal of lignin and part of the hemicellulose, favoring increased enzymatic digestibility of the pretreated material (Perrone et al., 2016). Ultrasound works by means of a phenomenon called acoustic cavitation and has been used in various studies as a pretreatment of lignocellulosic materials (Liu et al., 2007; Sun, Sun, Sun, \& Su, 2004; Velmurugan \& Muthukumar, 2011). Alkaline pretreatment of lignocellulosic materials has also been reported as a pretreatment for the deconstruction of lignocellulosic materials (Fan, Gharpuray, \& Lee, 1987; Bi, Peng, Chen, \& Zhu, 2016).

The most ecologically friendly alternative to produce biofuel is via the enzymatic route, which requires cellulolytic and hemicellulolytic enzymes to depolymerize the biomass into fermentable sugars. Factors affecting enzymatic hydrolysis include substrate type, cellulolytic activity and reaction conditions (temperature, $\mathrm{pH}$, enzyme 
concentration and others). To improve yields and rates of enzymatic hydrolysis, there are studies focusing on optimizing the hydrolytic process and on achieving high enzyme rates (Cantwell, Sharp, Gormley, \& Mcconnell, 1988; Lopes, Ferreira, \& Moreira, 2018).

However, the cost of commercial enzymes is the main limiting factor for making $2 \mathrm{G}$ production via the enzymatic route feasible (Mishima, Tateda, Ike, \& Fujita, 2006). In this context, studies on how to produce cellulases and hemicellulases at lower costs are extremely important.

Solid-state cultivation (SSC) is an efficient process for obtaining extracts containing a high concentration of enzyme that can be applied in the hydrolysis of lignocellulosic materials. One of the main advantages of SSC is the possibility of using agricultural waste as substrates. Nevertheless, this kind of bioprocess is still not applied on an industrial scale, due to lack of appropriate commercial bioreactors (Casciatori, Bück, Thoméo, \& Tsotsas, 2016).

Among the available bioreactors for SSC, packed-bed bioreactors (PBB) are quite suitable and have been successfully used for the production of cellulolytic and hemicellulolytic enzymes (Zanelato, Shiota, Gomes, \& Thoméo, 2012; Casciatori, Casciatori, \& Thoméo, 2013). A PBB is a relatively simple equipment, easy to handle and with low operational requirements. It consists of an inner tube, in which the substrate is packed, usually surrounded by a jacket, through which water circulates at a controlled temperature. Its static bed characteristic makes it ideal for microorganisms sensitive to shear stress, as is the case of some filamentous fungi that could have their hyphae ruptured by bed movement, hindering the development of the microorganism (Perez, Casciatori, \& Thoméo, 2019).

Thermophilic fungi are of particular interest in this context, as they adapt better to possible temperature increases during the solid state cultivation process, especially on a large scale. In addition, they generally produce more stable enzymes at high temperatures, a desirable characteristic for various biotechnological and/or industrial applications, including the hydrolysis of lignocellulosic materials such as sugarcane bagasse (Silva, Lago, Merheb, Macchione, \& Park, 2005). The thermophilic fungus Myceliophthora thermophila produces endoglucanase and endoxylanase, acting internally on substrates, with outstanding enzyme activities (Zanelato et al., 2012).

On all the above, the objective of this work was to produce cellulases from the thermophilic fungus Myceliophthora thermophila I-1D3b by SSC in a PBB and to evaluate the efficiency of the enzymatic extracts in the hydrolysis of SCB in natura (BIN) and pretreated with ozone, alkali and ultrasound (BOU).

\section{Material and Methods}

\section{Substrate and Microorganism}

Wheat bran (WB) was acquired from local commerce in São Jose do Rio Preto, SP, Brazil. Sugarcane bagasse (SCB) was kindly provided by Usina Vale, Onda Verde, SP, Brazil. The SCB was washed with distilled water, until residual sugar was no longer detected by the qualitative determination of total reducing sugars following the method described by Miller (1959). The wet material was then oven dried at $50^{\circ} \mathrm{C}$ until constant weight, ground in a knife mill and then sieved using 4 and $3 \mathrm{~mm}$ sieves. The material that passed through the $4 \mathrm{~mm}$ sieve and that was retained by the $3 \mathrm{~mm}$ sieve was used for the cultivation. Both substrates were packed in polyethylene bags and kept under refrigeration at $4^{\circ} \mathrm{C}$ until use.

The fungus Myceliophthora thermophila I-1D3b was inoculated in Petri dishes containing Sabouraud Dextrose Agar (HiMedia Laboratories Pvt. Ltd., Mumbai, India) and kept in a culture chamber for $48 \mathrm{~h}$ at $45^{\circ} \mathrm{C}$. The spores were suspended with 100 $\mathrm{mL}$ of nutrient solution containing $0.35 \%\left(\mathrm{~W} \mathrm{~V}^{-1}\right)$ 
$\left(\mathrm{NH}_{4}\right)_{2} \mathrm{SO}_{4}, 0.3 \%\left(\mathrm{w} \mathrm{v}^{-1}\right) \mathrm{KH}_{2} \mathrm{PO}_{4}, 0.05 \%\left(\mathrm{w} \mathrm{v}^{-1}\right)$ $\mathrm{MgSO}_{4} .7 \mathrm{H}_{2} \mathrm{O}, 0.05 \%\left(\mathrm{w} \mathrm{v}^{-1}\right) \mathrm{CaCl}_{2}$ and $0.1 \%(\mathrm{v}$ $\mathrm{v}^{-1}$ ) Tween 20 at pH 5.0 (Zanelato et al., 2012). An aliquot of suspension was taken for spore counting in Neubauer chamber.

\section{Cultivations in $P B B$}

The PBB was composed of 10 jacketed modules with internal diameter $7.62 \mathrm{~cm}$. Each module was 10 $\mathrm{cm}$ high, hence the bioreactor reached a height of 1 $\mathrm{m}$ by connecting 10 consecutive modules vertically. Water circulated through the jacket in order to keep wall temperature constant (Casciatori et al., 2013). A photo of the 1 meter long PBB is shown in Figure

1. The temperature in the center of the bed was monitored at different heights by means of radially installed T-type thermocouples through union flanges placed in between consecutive modules. Thermocouple electrical signals were recorded by the COMPAQ-DAQ ${ }^{\mathrm{TM}}$ data acquisition system using a routine managed in LabVIEW ${ }^{T M}$ (National Instruments, Austin, USA). The conditions for enzyme production in the $\mathrm{PBB}$ were as follows: substrate composition SCB/WB 2.3:1 (w/w), with a moisture content of $75 \%$ on a wet basis (wb), reached by adding the appropriate volume of the above mentioned nutrient solution; wall and inlet air temperature $45^{\circ} \mathrm{C}$; end-to-end ascendant aeration rate of $240 \mathrm{~L} \mathrm{~h}^{-1}$, for a total time of $96 \mathrm{~h}$ (Casciatori et al., 2013; Zanelato et al., 2012).

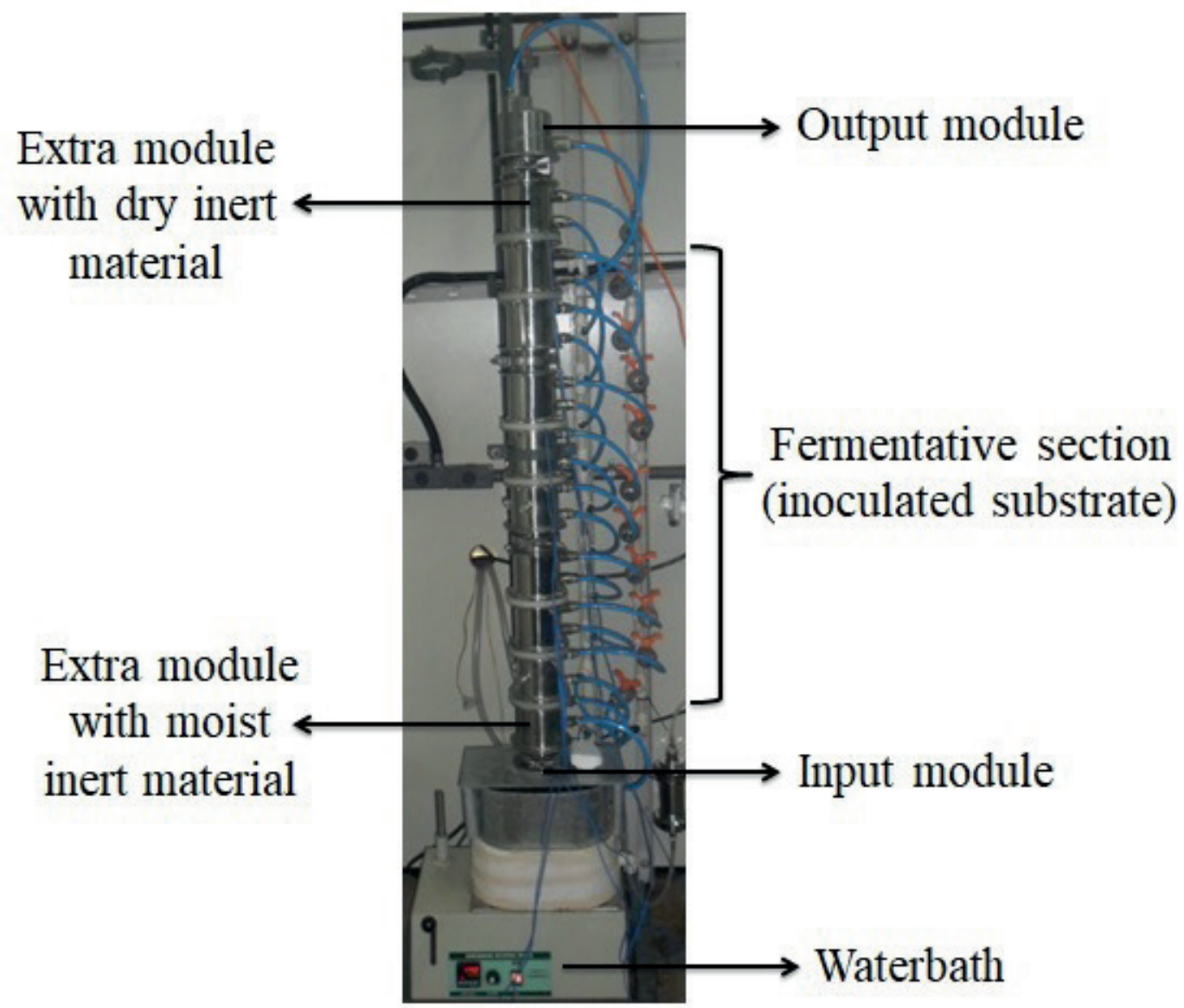

Figure 1. PBB with 10 modules ( $1 \mathrm{~m}$ long): modules 2 to 9 filled with inoculated material; module 1 packed with non-inoculated SCB (just to avoid drying of the next modules); module 10 packed with dry SCB (to absorb dripping condensate); input and output modules internally conic; input module filled with glass beads (to distribute percolating airflow). 
The fermentations were performed in triplicate. Prior to the cultivations, the dry substrates were weighed (45 g per module) and autoclaved (121 $\left.{ }^{\circ} \mathrm{C}, 1.1 \mathrm{~atm}, 20 \mathrm{~min}\right)$ in polypropylene plastic bags. After sterilization, the substrates were inoculated separately with the spore suspensions, humidified and aseptically homogenized just before being packed into the modules of the PBB. The spore concentration was fixed at $10^{7}$ spores $/ \mathrm{mL}$, using a hemocytometer, and $1 \mathrm{~mL}$ was added to each plastic bag. At the end of the process, the fermented substrate was removed from the respective modules for enzyme extraction. Aliquots of each module were used to determine the final moisture content. Enzymes were recovered from the fermented material by solid-liquid extraction. The total content of each module was mixed with $20 \mathrm{~mL}$ of distilled water per gram of initial dry solid substrate and stirred in an orbital chamber for $30 \mathrm{~min}$ at $100 \mathrm{rpm}$. The extracts were then filtered and centrifuged (10.000 rpm, $15 \mathrm{~min}, 5{ }^{\circ} \mathrm{C}$ ) (Zanelato et al., 2012). The supernatants were used for enzymatic activities determinations, as well as for SCB hydrolysis tests.

\section{Enzyme activities determination}

The carboxymethylcellulase (CMCase) and filter paper (FPU) activities were determined by enzymatic reactions using as substrates, respectively, $4 \%$ of carboxymethylcellulose (Sigma Aldrich, St. Louis, USA $)$ and $50 \mathrm{mg}(1 \times 6 \mathrm{~cm}$ strip $)$ of Whatman no. 1 filter paper, both in sodium acetate buffer $(0.1 \mathrm{~mol}$ $\mathrm{L}^{-1}, \mathrm{pH}$ 5.0), following IUPAC procedures (Ghose, 1987) with modifications. Xylanase activity was determined by enzymatic reaction using as substrate $1 \%$ of xylan (Birchwood - Sigma Aldrich, St. Louis, USA $)$ in sodium acetate buffer $\left(0.1 \mathrm{~mol} \mathrm{~L}^{-1}, \mathrm{pH}\right.$ 5.0), according to Bailey, Peterbiely and Poutanen (1992). These enzymatic reactions were carried out at $60{ }^{\circ} \mathrm{C}$. The amount of total reducing sugars (TRS) released by the enzymatic reactions was determined by 3,5-dinitrosalicylic acid (DNS) (Miller, 1959). For CMCase and FPU, one unit of enzyme activity
(U) was defined as the amount that released 1 $\mu \mathrm{mol}$ of glucose per minute under the reaction conditions, by using glucose standard curves at 540 $\mathrm{nm}$. For xylanase, one unit of enzyme activity (U) was defined as the amount that released $1 \mu \mathrm{mol}$ of xylose per minute under the reaction conditions, by using xylose standard curves at $540 \mathrm{~nm}$.

$\beta$-glucosidase activity was quantified by enzymatic reaction using as substrate 4-nitrophenyl $\beta$-D-glucopyranoside $4 \mathrm{mmol} \mathrm{L}^{-1}$ (PNPG, Sigma) in sodium acetate buffer $\left(0.1 \mathrm{~mol} \mathrm{~L}^{-1}, \mathrm{pH} 5.0\right)$, according to Leite et al. (2007), also at $60{ }^{\circ} \mathrm{C}$. One unit of enzymatic activity was defined as the amount that released $1 \mu \mathrm{mol}$ of $p$-nitrophenol per minute of reaction. A standard curve of $p$-nitrophenol at 410 nm was used.

For expressing all enzyme activities as units per gram of solid substrate $\left(\mathrm{U} \mathrm{gss}^{-1}\right)$, results in $\mathrm{U} \mathrm{mL}^{-1}$ have been multiplied by the solid-liquid extraction

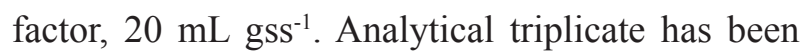
used.

\section{Pretreatment of $S C B$}

Prior to being pre-treated, SCB (already washed and oven dried), was crushed and separated using 0.84 and $0.42 \mathrm{~mm}$ sieves. Particles which passed through the $0.84 \mathrm{~mm}$ mesh and which were retained on the $0.42 \mathrm{~mm}$ sieve were divided to be used as $\mathrm{BIN}$ or to be sent for pretreatment.

The pretreatment of SCB with ozone, alkali and ultrasound (BOU) was based on that proposed by Perrone et al. (2016). $\mathrm{O}_{3}$ gas was obtained using the Radast 10C generator (Ozoxi-ozone, São José dos Campos, Brazil). The ultrasound irradiation was done using a Model 50 Sonic Dismembrator ultrasonic probe (Fisher Scientific, Hampton, USA), operating at a frequency of $22 \mathrm{kHz}$ and power of $50 \mathrm{~W}$. For the pretreatment, $20 \mathrm{~g}$ of dry SCB with particle size between 0.42 and $0.84 \mathrm{~mm}$ were moisturized with $10 \mathrm{~mL}$ of alkaline solution (0.1 mol L-1 $\mathrm{NaOH})$, packed in glass columns $(2.7$ 
$\mathrm{cm}$ diameter $\mathrm{x} 50 \mathrm{~cm}$ length) and treated with ozone (flowrate $32 \mathrm{mg} \mathrm{O}_{3} \mathrm{~min}^{-1}$ for $60 \mathrm{~min}$ ). After ozonation, the SCB was immersed in $400 \mathrm{~mL}$ of alkaline solution $\left(0.1 \mathrm{~mol} \mathrm{~L}^{-1} \mathrm{NaOH}\right)$ and irradiated with ultrasound for $5 \mathrm{~min}$. After the ultrasound treatment, the material was kept at rest for 2 hours, after which it was washed with distilled water, dried at $60{ }^{\circ} \mathrm{C}$ until constant weight and stored, protected from light, for later use in the enzymatic hydrolysis step.

\section{Experimental design for the SCB hydrolysis}

The experimental design for evaluating hydrolysis efficiency was a rotational composite central design with response surface analysis. The chosen factors were volume of enzyme extract and hydrolysis duration (13 runs, 8 conditions +5 replications on central point). Enzymatic hydrolysis was carried out in Erlenmeyer flasks containing 0.2 $\mathrm{g}$ of BIN or of BOU. Different volumes of crude enzymatic extract $\left(0.6 \mathrm{FPU} \mathrm{mL}^{-1}\right)$ were added to each flask and final volume was completed to 10 $\mathrm{mL}$ with sodium acetate buffer $0.2 \mathrm{~mol} \mathrm{~L}^{-1} \mathrm{pH}$ 5.0. The Erlenmeyer flasks were placed in an orbital shaker at $150 \mathrm{rpm}$ at $65^{\circ} \mathrm{C}$. It is important to note that the enzymatic extract used for the hydrolysis resulted from mixing the extracts from each PBB module, from all three fermentations runs. Enzyme activity was determined just before carrying out the hydrolysis experiments. Moreover, all the hydrolysis tests were run simultaneously, using the same enzyme extract in all of the flasks.

Minitab ${ }^{\circledR} 15.1$ software (Minitab Inc., State College, USA) was used to create and analyze the experimental design. At central points, $5 \mathrm{~mL}$ of enzyme extract were applied and hydrolysis last 4 $\mathrm{h}$; levels \pm 1.41 (2.2 and $7.8 \mathrm{~mL} ; 1.2$ and $6.8 \mathrm{~h}$ ) and \pm 1 (3.0 and $7.0 \mathrm{~mL} ; 2$ and $6 \mathrm{~h}$ ) of both factors were tested. The levels of both variables were chosen based on Frassatto et al. (2020), who analyzed the kinetics of enzymatic saccharification of BIN for up to $24 \mathrm{~h}$.
For BIN and BOU, individual (but identical) designs were run independently. The response variable was TRS released, in mg per $g$ of BIN or of BOU. Statistical analyses included a Pareto chart (Student's-t), ANOVA and Response Optimizer.

\section{Quantification of TRS released from hydrolysis}

TRS released during the hydrolysis were quantified following Miller (1959) in analytical triplicate. A sample of filtered hydrolysate was boiled with DNS (3,5-dinitrosalicylic acid) reagent. Absorbance was read at $540 \mathrm{~nm}$ and a glucose standard curve was used for expressing the results as mg of TRS per gram of SCB ( $\left.\mathrm{mg} \mathrm{g}^{-1}\right)$.

The percentage of conversion of cellulose into glucose was calculated using Equation 1, according to Afonso (2012):

$\mathrm{X}(\%)=\mathrm{C}_{\text {glucose }} \times \mathrm{V} \times \mathrm{FE} \times 100 \times(1 / \mathrm{f}) / \mathrm{m}_{\text {offered }}$

where $\mathrm{X}(\%)$ is the percentage of cellulose converted; $\mathrm{C}_{\text {glucose }}\left(\mathrm{g} \mathrm{L}^{-1}\right)$ is the glucose concentration from the hydrolysis; $\mathrm{V}(\mathrm{L})$ is the total volume of the solution added for the hydrolysis $(10 \mathrm{~mL}) ; \mathrm{m}_{\text {offered }}(\mathrm{g})$ is the dry mass of material offered for hydrolysis; $f$ $\left(g_{\text {cellulose }} g_{\text {offered }}^{-1}\right)$ is the mass fraction of cellulose in the material offered for hydrolysis: $51.8 \%$ for BOU and $41.3 \%$ for BIN (Perrone et al., 2016); FE is the stoichiometric factor of the ratio of cellulose to glucose, which is equal to 0.9 (Afonso, 2012).

\section{Chemical composition analysis of SCB and quantification of sugar content}

The composition of the structural carbohydrates cellulose, hemicellulose and lignin and ash content of the SCB were determined following the methodology of National Renewable Energy Laboratory (NRE - USA), Laboratory Analytical Procedures NREL/TP 510-42618 (Sluiter et al., 2008). 
Quantification of glucose and xylose was carried out using a Dionex, ICS-5000 high-performance anion-exchange chromatograph with pulsed amperometric detection (HPAEC-PAD) (Thermo Scientific, Waltham, USA). A CarboPac ${ }^{\circledR}$ PA-1 anion exchange column with compartments at $25^{\circ} \mathrm{C}$ and $30{ }^{\circ} \mathrm{C}$ was used, diluents were prepared with ultrapure deionized water $18 \mathrm{M} \Omega$ and degassed with $\mathrm{N}_{2}$. Flow was $1 \mathrm{~mL} \mathrm{~min}^{-1}$ of solvent A (ultrapure water) and $\mathrm{B}\left(500 \mathrm{mmol} \mathrm{L}^{-1} \mathrm{NaOH}\right)$. Isocratic elution was used for column cleaning from 0 to 12 min with $95.2 \% \mathrm{~A}$; from 12 to $16 \mathrm{~min}, 100 \% \mathrm{~B}$ was used; and from 16 to $30 \mathrm{~min}, 95.2 \%$ of A was eluted to end the process (Perrone et al., 2016). The results were quantified based on standard curves of glucose and xylose (Sigma-Aldrich, St Louis, USA).

\section{Results and Discussion}

\section{Enzyme production in the $P B B$}

Figure 2 shows the results of CMCase, xylanase, FPU and $\beta$-glucosidase ( $\mathrm{U}$ gss $^{-1}$ ) activities at different heights of the PBB. The horizontal lines refer to global activity (average of the 8 fermentative modules). In general, higher enzyme activities were produced at the lower modules of the column and lower activities were seen in higher modules of the PBB. The same trend had previously been reported by Derakhti, Shojaosadati, Hashemi and Khajeh (2012), who studied the production of $\alpha$-amylase by Bacillus sp. KR-8104 using WB as substrate also in a PBB.
The level of fluctuation of enzyme activity observed in these experiments may be accepted as normal, in spite of the triplicate used. Despite some advantages, SSC still has some bottlenecks to face. These include problems with oxygen transfer, removing metabolic heat and water activity distribution through the solid substrate particles. In addition, there is also heterogeneity of the solid substrate in the bioreactor to consider. All these parameters are relevant and interfere with optimal physiological conditions for the mycelia mode microorganism growth, as well as it physiological capability ofmetabolite(enzyme) production(Manan $\&$ Webb, 2017). So, some variation on enzyme yield during SSC might be expected, especially in a long vertical PBB experiment. In this bioreactor, the fresh air is supplied at the bottom, hence oxygen is gradually consumed by the microbial cells along the column, as well as the carbon dioxide released by the fungal metabolism is dragged by advection with the gas stream in ascendant direction. Therefore, the gas-phase becomes less concentrated in oxygen and more concentrated in carbon dioxide at the upper modules of the PBB. Even so, the enzyme activity profile found here can be considered relatively homogeneous, with some heterogeneity being justified by intrinsic process limitations, as already reported by Zanelato et al. (2012), Casciatori et al. (2013), Derakhti et al. (2012) and Perez et al. (2019). 
(A)

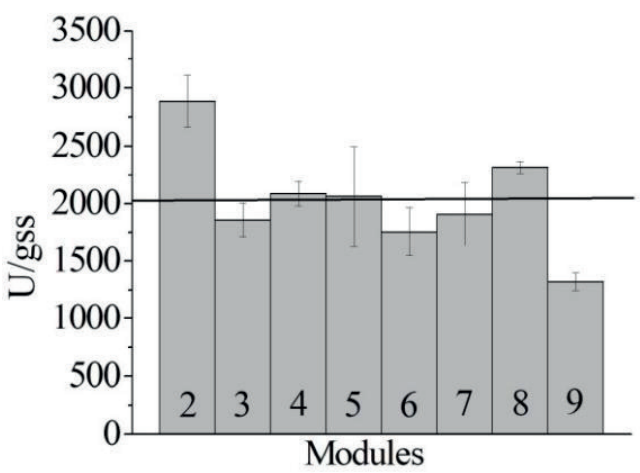

(C)

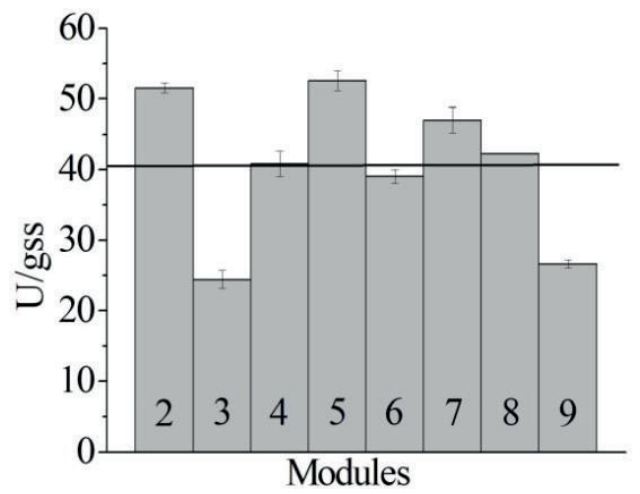

(B)

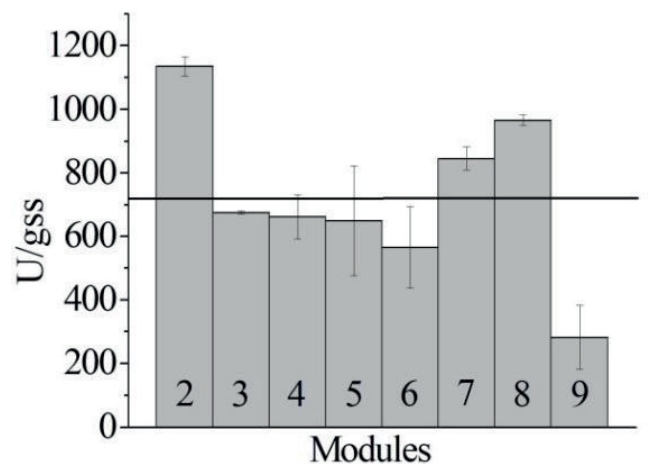

(D)

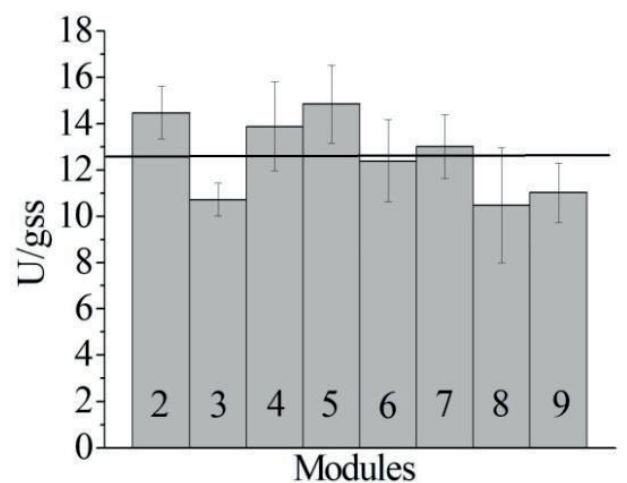

Figure 2. Enzymatic activities up the PBB:

(A) Xylanase; (B) CMCase; (C) $\beta$-glucosidase; (D) FPU (- Average of enzymatic activities for the 8 modules of the PBB).

The highest CMCase, xylanase, FPU and $\beta$-glycosidase activities were obtained in module 2, respectively, $1135 \mathrm{U} \mathrm{gss}^{-1}, 2885 \mathrm{U} \mathrm{gss}^{-1}, 14.5$ $\mathrm{U} \mathrm{gss}^{-1}$ and $51.5 \mathrm{U} \mathrm{gss}^{-1}$. Enzymatic hydrolysis of cellulose requires mixtures of hydrolytic enzymes, including endoglucanases, exoglucanases (cellobiohydrolases) and $\beta$-glucosidases, acting synergistically. Considering FPU activity as representative of the total system of the three cellulases present in the crude extract, it could be expected that variations in FPU and $\beta$-glucosidase activities along the PBB would be similar, since $\beta$-glucosidase is generally the limiting enzyme acting in cellulose hydrolysis (Molina, Contesini, Melo, Sato, \& Pastore, 2016). $\beta$-glucosidase is responsible for making the final disruption of the dimers (cellobiose) into glucose monomers, which is important for preventing cellobiose to accumulate and consequently inhibit cellulose degradation by other enzymes (Sandgren, Stahlberg, \& Mitchinson, 2005).

The average enzyme activities CMCase (723 U gss $^{-1}$ ), xylanase (2024 U gss ${ }^{-1}$ ), FPU (12.6 U gss $\left.{ }^{1}\right)$ and $\beta$-glucosidase (40.5 $\mathrm{U} \mathrm{gss}^{-1}$ ) yielded from the PBB in the current study are very promising when compared to results reported by previous papers in the literature in which authors used other Myceliophthora species cultivated on different substrates. They report CMCase, xylanase, FPU and $\beta$-glucosidase activities in the ranges of 6 to 800,129 to 10450.6 to 8.3 and 30.5 to $41.8 \mathrm{U}$ gss $^{-1}$, respectively (Soni, Nazir, Chadha, \& Saini, 2008; Badhan, Chadha, Kaur, Saini, \& Bhat, 2007; Zanelato et al., 2012; Moretti et al., 2012; Pereira, Travaini, Marques, Bolado-Rodríguez, \& Martins, 2016; Oliveira Rodrigues et al., 2017). 
It is known that temperature of the fermentation process affects microbial growth and product formation; temperatures above the optimal one might harm fungal growth and present adverse effects on enzyme yields and productivities (Mitchell, Pandey, Sangsurasak, \& Krieger, 1999; Perez et al., 2019). However, Figure 3A shows a maximum temperature during the process of $47^{\circ} \mathrm{C}$,

(A)

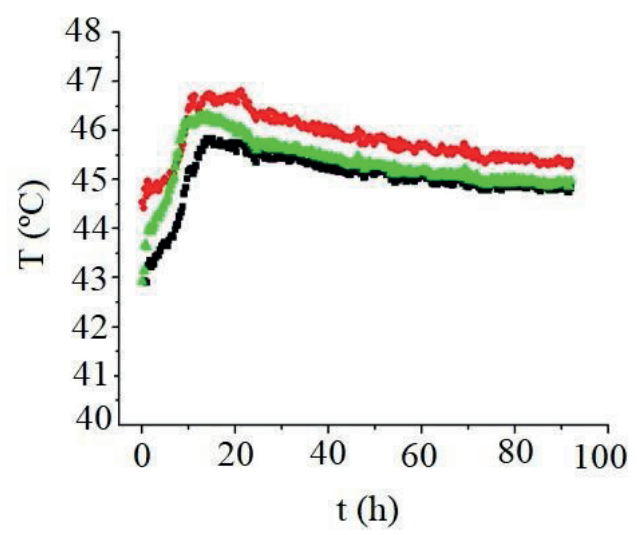

in other words, overheating was negligible during this SSC, which is a very interesting attribute for industrial applications. This indicates that the random longitudinal variations of enzyme activities showed in Figure 2 is probably more associated with non-controllable biological or biochemical concerns than to engineering aspects of the PBB.

(B)

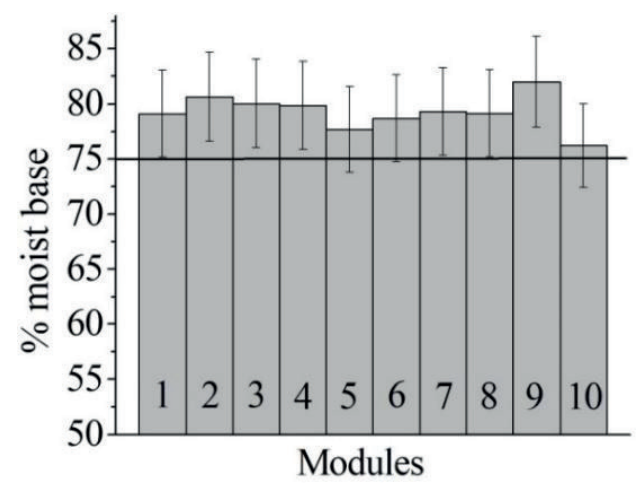

Figure 3. Temperature (A) and final moisture content (B) profiles in the PBB. $(\bullet) \mathrm{z}=0.2 \mathrm{~m} ;(\boldsymbol{\Delta}) 0.5 \mathrm{~m}$;

(-) $0.8 \mathrm{~m}$; (- Initial moisture content of the substrate). Results from triplicate of the fermentations are comprised.

Thermal control of PBBs is known to depend on several factors, such as the physiology and growth rate of the microorganism, the physical properties of the solid material, the equipment dimensions and the operational conditions. The combination of substrate, microorganism and PBB design and operational conditions chosen in the current paper avoided the problem of hot spot formation, which is a drawback extensively discussed in the literature as the main disadvantage of PBBs for SSC (Ghildyal, Gowthaman, Raghava Rao, \& Karanth, 1994; Mitchell, Krieger, \& Berovic, 2006).

Kalogeris et al. (2003) had also reported mild temperature elevations in their fermentation experiments using an intermittently agitated bioreactor for the cultivation of the thermophilic fungus Thermoascus aurantiacus with wheat straw as substrate and at temperatures of 45, 49 and 53 ${ }^{\circ} \mathrm{C}$. These authors reported actual bed temperatures of $44.3 \pm 1.1 ; 48.4 \pm 0.9$ and $52.2 \pm 1.3{ }^{\circ} \mathrm{C}$, reinforcing the hypothesis that the temperature increase due to the metabolic heat generation when using thermophilic strains is lower than when using mesophilic fungi.

Figure 3B shows the final moisture contents of the fermented material. It is important to remember that enzyme production has actually taken place from Module 2 to 9 . Module 1 was packed with non-inoculated SCB at $75 \%$ moisture content (wb) and Module 10 with dry and also non-inoculated $\mathrm{SCB}$. These additional non-fermentative modules were added to the PBB in order to avoid drying or moisture migration up the column, a problem previously reported by Zanelato et al. (2012) and 
Casciatori et al. (2013). They observed that, when the air was going to leave the PBB, the water vapor (carried by the flowing saturated air at $45^{\circ} \mathrm{C}$ ) condensed because room temperature was lower than the temperature inside the bed. Consequently, the condensed water dripped on the substrate contained within the upper modules. Even when packing dry SCB in Module 10, as in the current work, moisture content increased in Module 9, and enzymatic activities from that module were systematically lower.

A reasonable explanation for this effect is that condensed water blocked the void spaces in between the particles of the bed, hindering flow and gas exchange and consequently negatively affecting the microbial metabolism and enzyme production. On the other hand, the highest activity levels achieved in Module 2 can be attributed precisely to its proximity to the air inlet in the bioreactor. In this section, air is still fresh, rich in oxygen and free of fermentation gases.

\section{Hydrolysis of BIN and BOU}

Table 1 shows TRS released from hydrolysates of BIN and BOU, expressed in mg of glucose per gram of $\mathrm{SCB}$, as well as the equivalent percentage of conversion of cellulose into glucose (Equation 1).

\section{Table 1}

Total reducing sugars (TRS) released and conversion of cellulose into glucose in the enzymatic hydrolysis of SCB (BIN and BOU) using enzyme extract produced by SSC of Myceliophthora thermophila according to central composite experimental design

\begin{tabular}{cccccccc}
\hline $\begin{array}{c}\text { Exp. } \\
\#\end{array}$ & $\begin{array}{c}\text { Volume of } \\
\text { enzyme } \\
(\mathrm{mL})\end{array}$ & $\begin{array}{c}\text { Enzyme load } \\
(\mathrm{FPU})\end{array}$ & $\begin{array}{c}\text { Time of } \\
\text { hydrolysis } \\
(\mathrm{h})\end{array}$ & $\begin{array}{c}\text { TRS } \\
\left(\mathrm{mg} \mathrm{g}^{-1}\right)\end{array}$ & $\begin{array}{c}\text { BIN } \\
\text { Conversion to } \\
\text { Glucose }(\%)\end{array}$ & $\begin{array}{c}\text { TRS } \\
\left(\mathrm{mg} \mathrm{g}^{-1}\right)\end{array}$ & $\begin{array}{c}\text { Conversion to } \\
\text { Glucose (\%) }\end{array}$ \\
\hline 1 & 3 & 1.8 & 2 & 22.6 & 5.2 & 75.3 & 13.9 \\
2 & 7 & 4.2 & 2 & 40.6 & 9.4 & 99.7 & 18.3 \\
3 & 3 & 1.8 & 6 & 28.0 & 6.5 & 126.9 & 23.4 \\
4 & 7 & 4.2 & 6 & 58.4 & 13.5 & 174.6 & 32.1 \\
5 & 2.2 & 1.3 & 4 & 22.3 & 5.2 & 98.2 & 18.1 \\
6 & 7.8 & 4.7 & 4 & 43.9 & 10.2 & 162.6 & 30.0 \\
7 & 5 & 3.0 & 1.2 & 30.7 & 7.1 & 89.0 & 16.4 \\
8 & 5 & 3.0 & 6.8 & 34.3 & 8.0 & 146.9 & 27.1 \\
9 & 5 & 3.0 & 4 & 34.0 & 7.9 & 133.3 & 24.6 \\
10 & 5 & 3.0 & 4 & 36.7 & 8.5 & 152.8 & 28.2 \\
11 & 5 & 3.0 & 4 & 36.1 & 8.4 & 124.1 & 22.9 \\
12 & 5 & 3.0 & 4 & 48.9 & 11.4 & 130.5 & 24.1 \\
13 & 5 & 3.0 & 4 & 42.3 & 9.8 & 131.3 & 24.2 \\
\hline
\end{tabular}

The chemical composition of SCBs hydrolyzed in this work were: $\mathrm{BIN}, 41.3 \pm 2.7 \%$ cellulose, $19.3 \pm 0.6 \%$ hemicellulose and $30.7 \pm 2.7 \%$ lignin; and BOU, $51.8 \pm 2.2 \%$ cellulose, $11.2 \pm$ $0.6 \%$ hemicellulose, $22.3 \pm 0.8 \%$ lignin and $3.1 \pm$
$0.3 \%$ ashes (Perrone et al., 2016). Hydrolysis of BOU released more TRS $\left(\approx 175 \mathrm{mg} \mathrm{g}^{-1}\right)$ than of BIN $\left(\approx 58 \mathrm{mg} \mathrm{g}^{-1}\right)$. Hence, BOU proved to be an efficient pretreatment to increase the enzymatic hydrolysis of $\mathrm{SCB}$, providing a much greater 
cellulose-into-glucose conversion. This is because the BOU pretreatment increases the surface area of SCB, increasing the contact between cellulases and the cellulose chain, resulting in an increase in the glucose released (Plácido \& Capareda, 2014). According to Perrone et al. (2016), the main advantage of the BOU pretreatment was the joint action of ozone and alkali, the latter promoting lignin degradation and hemicellulose removal, leaving the cellulose fully exposed to cellulase attack. In addition, the use of ultrasound irradiation under alkaline conditions helped to break down cell walls by facilitating solvent penetration (Liu et al., 2007). The irradiation effect along with the ozone/ alkali reactants potentiated the lignocellulosic material disruption, consequently increasing the enzymatic hydrolysis yields, as occurred in the present work. Pereira et al. (2016) also studied the saccharification of SCB submitted to ozone pretreatment by applying enzymes produced by

(A)

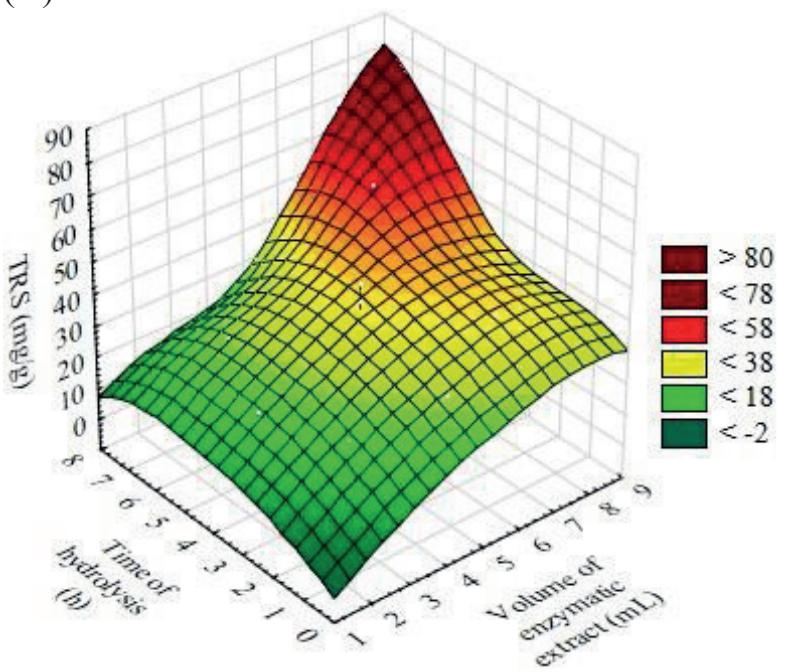

Myceliophthora thermophila JCP 1-4 and obtained promising results when compared to the application of commercial enzymes at $50{ }^{\circ} \mathrm{C}$.

Figure 4 shows the response surfaces of the hydrolysis of BIN and BOU. The hydrolysis yield was evaluated based on the TRS released. As shown by Figures 4 (A) and (B), the larger the volume of enzyme applied, the higher the amount of TRS released from BIN and BOU, respectively. Similarly, the longer the time of hydrolysis, the higher the conversion of cellulose. However, it must be remembered that overlong reaction times may deactivate the enzymes, as well as increase operational costs. Figures 4(A) and (B) also allow the inference that there was no limitation through lack of substrate to the catalytic sites of the enzymes, since extrapolations of the response surfaces suggest that TRS release would keep increasing for higher volumes of enzymatic extract applied to the BIN or to the BOU hydrolysis.

(B)

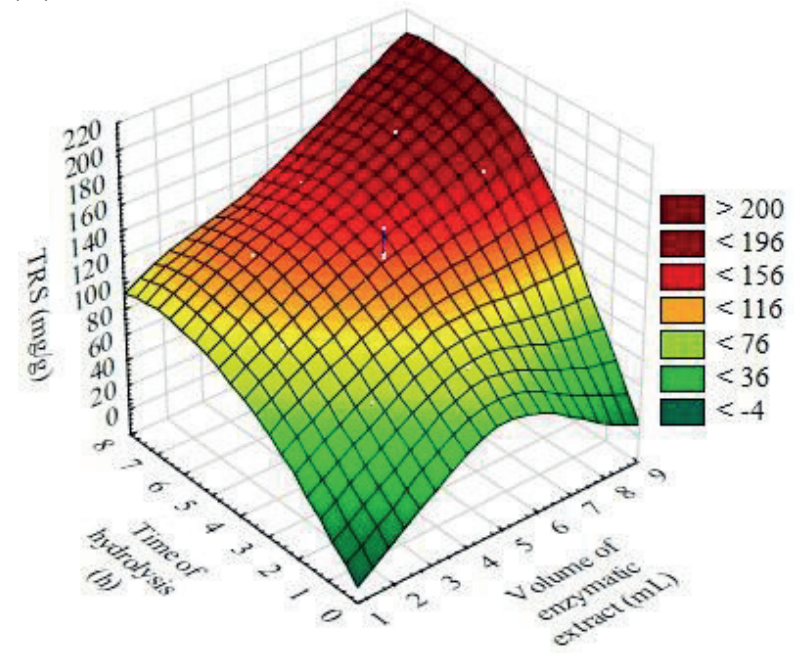

Figure 4. Response surfaces of hydrolysis, given by TRS as a function of hydrolysis time and volume of enzymatic extract used for (A) BIN; (B) BOU. 
Statistical analysis of the results from the experimental design allowed the plottong of Pareto charts for the response variable TRS released in the hydrolysis of BIN and BOU, shown in Figures 5 (A) and (B), respectively, representing graphically and numerically the effects of each factor, volume of enzyme extract

(A)

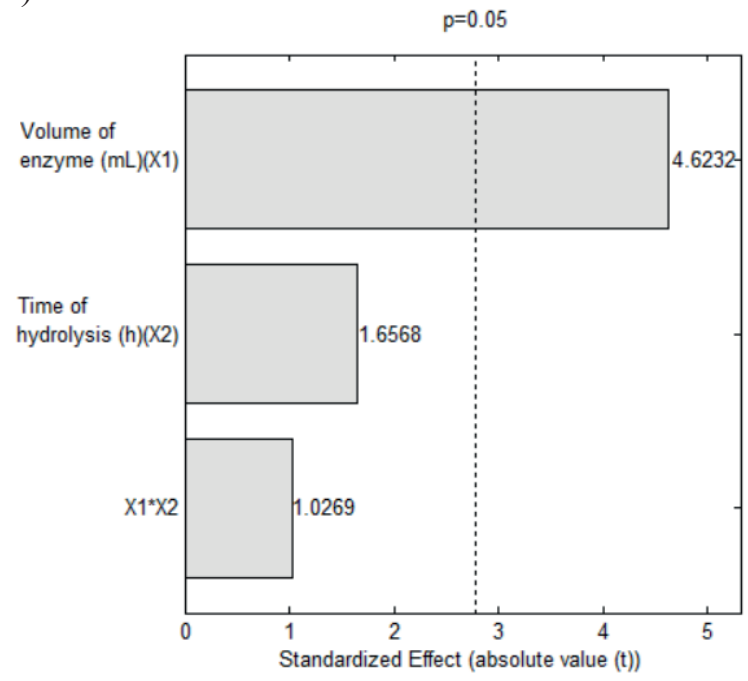

applied and time of hydrolysis, as well as the effect of their interaction. For the same response variable for BIN and BOU, analysis of variance (ANOVA) have been performed and the results are summarized in Tables 2 and 3, respectively, that also present model coefficients and predictive equations.

(B)

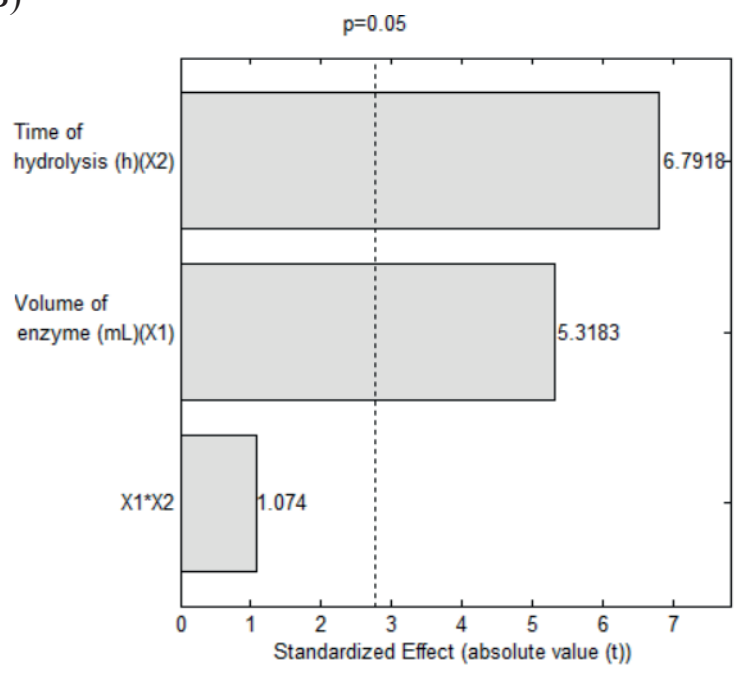

Figure 5. Pareto charts for the response variable TRS released (mg/g) in the hydrolysis of (A) BIN; and (B) BOU. 
Table 2

Analysis of variance and statistical model for the response variable total reducing sugars (TRS) released in the enzymatic hydrolysis of BIN

\begin{tabular}{|c|c|c|c|c|c|}
\hline \multicolumn{6}{|c|}{ Analysis of Variance } \\
\hline Source of variance & $\begin{array}{l}\text { Degree of } \\
\text { freedom }\end{array}$ & $\begin{array}{c}\text { Adjusted } \\
\text { Sum of } \\
\text { Squares }\end{array}$ & $\begin{array}{l}\text { Adjusted } \\
\text { Mean of } \\
\text { Squares }\end{array}$ & $\begin{array}{c}\text { F-value } \\
\text { (Fisher } \\
\text { statistics) }\end{array}$ & p-value \\
\hline Model & 5 & 980.24 & 196.05 & 5.10 & $0.027 *$ \\
\hline Linear & 2 & 879.13 & 439.56 & 11.44 & $0.006^{*}$ \\
\hline Volume of enzyme extract $(\mathrm{mL})$ & 1 & 779.08 & 779.08 & 20.28 & $0.003^{*}$ \\
\hline Time of hydrolysis (h) & 1 & 100.05 & 100.05 & 2.60 & 0.151 \\
\hline Square & 2 & 62.67 & 31.33 & 0.82 & 0.480 \\
\hline Volume*Volume & 1 & 30.68 & 30.68 & 0.80 & 0.401 \\
\hline Time*Time & 1 & 40.07 & 40.07 & 1.04 & 0.341 \\
\hline 2-Way Interaction & 1 & 38.44 & 38.44 & 1.00 & 0.351 \\
\hline Volume*Time & 1 & 38.44 & 38.44 & 1.00 & 0.351 \\
\hline Error & 7 & 268.95 & 38.42 & & \\
\hline Lack-of-Fit & 3 & 123.15 & 41.05 & 1.13 & 0.438 \\
\hline Pure Error & 4 & 145.80 & 36.45 & & \\
\hline Total & 12 & 1249.19 & & & \\
\hline \multicolumn{6}{|l|}{ Model summary } \\
\hline $\mathbf{S}$ & \multicolumn{2}{|c|}{ R-square } & $\begin{array}{l}\text { R-square } \\
\text { adjusted }\end{array}$ & \multicolumn{2}{|c|}{ R-square predicted } \\
\hline 6.19853 & \multicolumn{2}{|c|}{$78.47 \%$} & $63.09 \%$ & \multicolumn{2}{|c|}{$11.66 \%$} \\
\hline \multicolumn{6}{|l|}{ Coded Coefficients } \\
\hline Term & Effect & Coefficient & $\begin{array}{c}\text { t-value } \\
\text { t-Student } \\
\text { statistics) }\end{array}$ & \multicolumn{2}{|c|}{ p-value } \\
\hline Constant & & 39.60 & 14.29 & \multicolumn{2}{|c|}{$0.000 *$} \\
\hline Volume of enzyme extract (mL) & 19.74 & 9.87 & 4.50 & \multicolumn{2}{|c|}{$0.003 *$} \\
\hline Time of hydrolysis (h) & 7.07 & 3.54 & 1.61 & \multicolumn{2}{|c|}{0.151} \\
\hline Volume*Volume & -4.20 & -2.10 & -0.89 & \multicolumn{2}{|c|}{0.401} \\
\hline Time*Time & -4.80 & -2.40 & -1.02 & \multicolumn{2}{|c|}{0.341} \\
\hline Volume*Time & 6.20 & 3.10 & 1.00 & \multicolumn{2}{|c|}{0.351} \\
\hline
\end{tabular}

Regression Equation in Uncoded Units for TRS Released from Hydrolysis of BIN

$\mathrm{TRS}_{\text {BIN }}(\mathrm{mg} / \mathrm{g})=39.60+9.87 * \mathrm{Vol}(+3.54 *$ time $-2.10 * \mathrm{Vol} * \mathrm{Vol}-2.40 *$ time $*$ time $+3.10 *$ Vol $*$ time $)$

where $\mathrm{Vol}=$ Volume of enzyme extract applied $(\mathrm{mL})$; time $=$ Time of hydrolysis $(\mathrm{h})$; terms comprised inside the parenthesis are not significant in the prediction model. 
Table 3

Analysis of variance and statistical model for the response variable total reducing sugars (TRS) released in the enzymatic hydrolysis of BOU

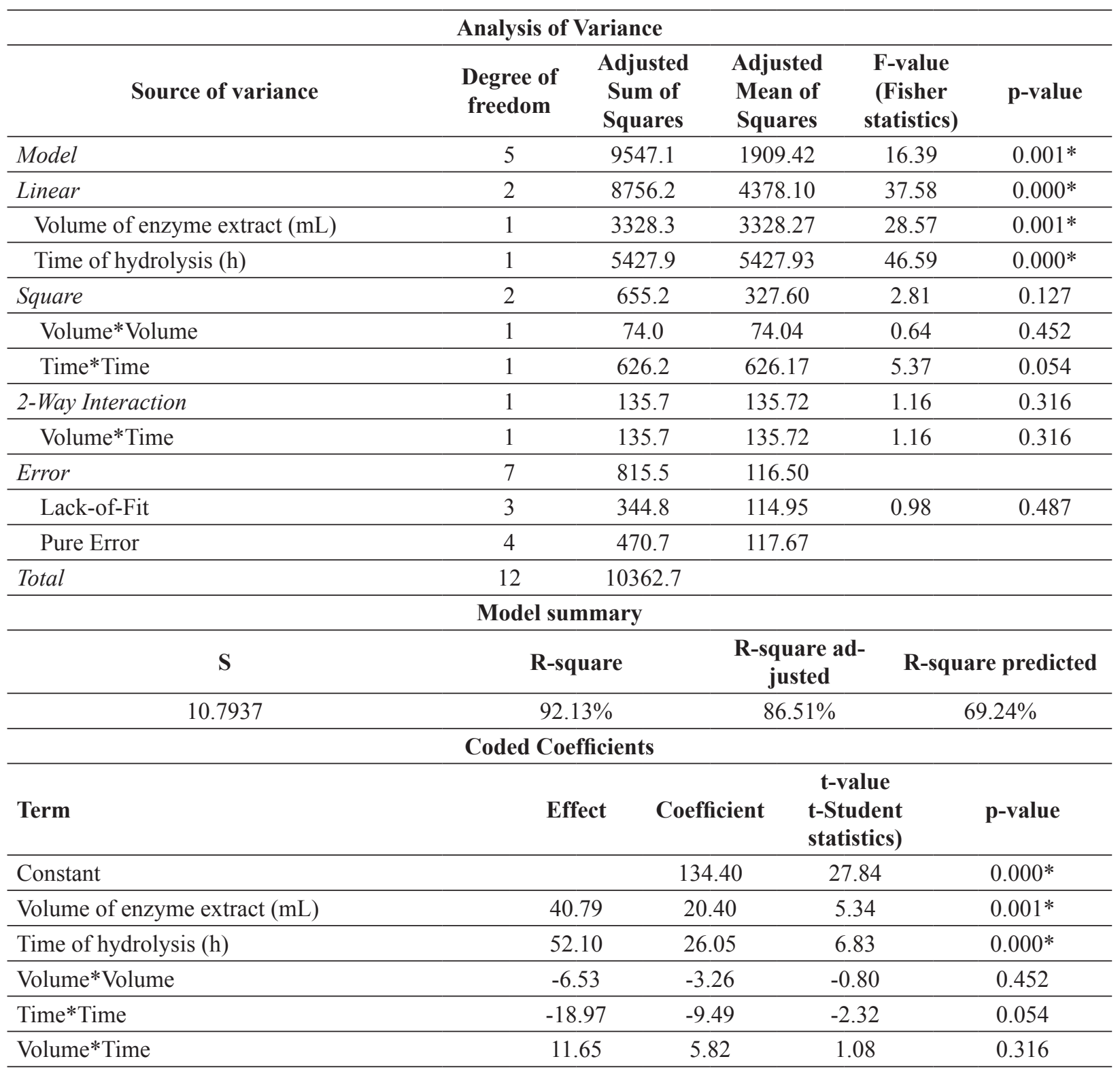

Regression Equation in Uncoded Units for TRS Released from Hydrolysis of BOU

$\mathrm{TRS}_{\text {воU }}(\mathrm{mg} / \mathrm{g})=134.4+20.4 * \mathrm{Vol}+26.05 *$ time $-9.49 *$ time $*$ time $\left(-3.26 * \mathrm{Vol}^{*} \mathrm{Vol}+5.82 * \mathrm{Vol}^{*}\right.$ time $)$

where $\mathrm{Vol}=$ Volume of enzyme extract applied $(\mathrm{mL})$; time $=$ Time of hydrolysis $(\mathrm{h})$; terms comprised inside the parenthesis are not significant in the prediction model; quadratic term time*time can be considered to play marginal effect $(p-v a l u e=0.054)$. 
The Pareto charts show the factors which are statistically significant ( $\mathrm{p}$-level $<0.05$ ), as well as the magnitude of the estimated effects of each factor and of their interaction on the response variable. The effects are represented by horizontal bars; only those bars that overpass the vertical line of $p$-level $=0.05$ have a statistically significant effect on the response variable, with a confidence level of $95 \%$, usually assumed for statistical analysis in biotechnological researches (Montgomery, 2001; Calado \& Montgomery, 2003). For BIN hydrolysis (Figure 5A), only the volume of enzyme had a significant positive effect (4.6232) on TRS released. This means the higher the volume of enzyme applied, the higher the yield of hydrolysis, in terms of TRS released. The time of hydrolysis also presented a positive effect (1.6568) as well as the interaction of both factors (1.0269) but neither time or interaction significantly affected the response variable. For BOU (Figure 5B), both volume of enzyme (5.3183) and time of hydrolysis (6.7918) had significant positive effects on TRS released while interaction had a non-significant positive effect (1.074). Hence, for hydrolysis of BOU, the yield of TRS increases significantly with positive increments in both enzyme volume and reaction time. Therefore, among the tests carried out, the best condition for the hydrolysis of both BIN and BOU can be chosen as Run \#4 (7 mL and 6 hours), although the Response Optimizer based on Desirability Function indicated all significant variables should be used at their highest values $(+1.41421)$ in order to maximize the response variable.

According to ANOVA for the TRS released from the enzymatic hydrolysis of BIN (Table 2), the magnitude order of the sum of squares for the linear effect of volume of enzyme was markedly higher than the correspondent values of all the other effects, which did not present statistical significance. This result addresses how strongly the hydrolysis of BIN depends on the volume of enzyme extract applied $(p$-value $=0.003)$. Additionally, the statistical model presented a reasonably good fit to the experimental results, with $78.5 \%$ of variance explained by the model and a lack-of-fit without statistical significance $(p$-value $=0.438)$. For the response variable of TRS released in enzymatic hydrolysis of BOU, ANOVA results are shown in Table 3. The magnitude order of the sum of squares for both linear effects (time of hydrolysis and volume of enzyme) was markedly higher than of the correspondent values of quadratic and interaction effects. This corroborates that only linear effects presented statistical significance, while quadratic and interaction effects did not. Only the square time*time presented a marginal statistical significance $(p$-value $=0.054)$. This result addresses that the hydrolysis of BOU depends strongly on both the volume of enzyme extract applied ( $p$-value $=0.001$ ) and even stronger on the time of hydrolysis ( $\mathrm{p}$-value $\approx 0.000$ ), probably because cellulose is much more freely accessible in the pretreated material. Additionally, the statistical model presented a very good fit to the experimental results, with $92.1 \%$ of variance explained by the model and a lack-offit without statistical significance (p-level = 0.487).

The glucose and xylose quantification determined by anion exchange chromatography (HPAEDPAD) for central points of the experimental design of BIN and BOU are presented in Figure 6. Sugar content increased significantly in the hydrolysate from BOU in comparison to the one from BIN. An increase of approximately 3.2 times in the amount of glucose and 12.8 times in the amount of xylose was observed. According to Travaini, Otero, Coca, Silva and Bolado (2013) and Perrone et al. (2016), ozonolysis is a promising pretreatment of SCB, since it leads to high yields of readily fermentable sugars like glucose (by C6 fermenting yeasts, like the well-known Saccharomyces cerevisiae) and xylose (by $\mathrm{C} 5$ fermenting yeasts, other wild species or recombinant $S$. cerevisiae, for instance). 


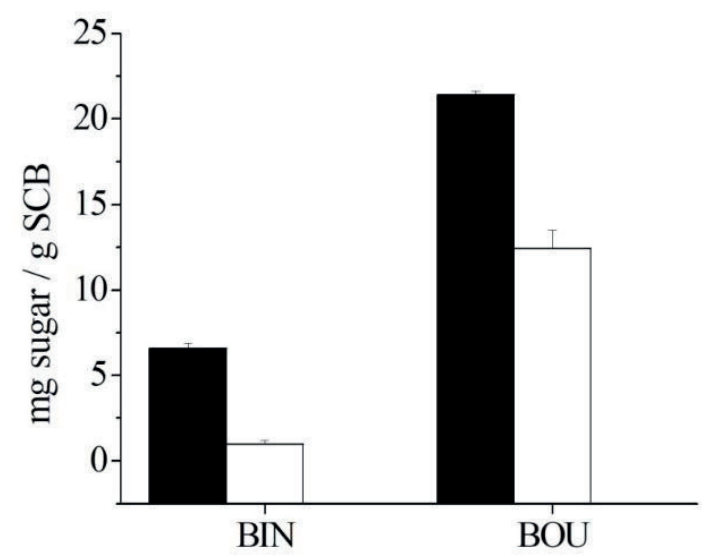

Figure 6. Sugar contents (HPAEC-PAD) in hydrolysates of BIN and BOU, from a reaction with $5 \mathrm{~mL}$ of enzyme (3 FPU) for 4 hours at 65 ${ }^{\circ} \mathrm{C}$. ( $\square$ ) glucose; ( $\square$ ) xylose.

The efficiency with which cellulose is hydrolyzed depends on many factors, from substrate characteristics to the nature of the enzyme system used. The factors related to the enzymes include inhibition of cellulolytic complex by accumulation of the end products (glucose and cellobiose) in the reactor, irreversible adsorption of enzymes on substrate and enzymatic deactivation by long exposure to high temperature and agitation. The factors related to the substrate correspond to porosity and crystallinity of cellulose fibers, as well as to lignin and hemicellulose contents (Florencio et al., 2017; Lopes et al., 2018). Biomass pretreatments disorganize the structure of lignocellulosic material and expose cellulose and hemicellulose to the action of the enzymes, increasing hydrolysis yields. Generally, hydrolysis of non-pretreated biomass yields less than $20 \%$ of conversion, while pretreatments can increase this result to more than $90 \%$ of conversion of cellulose into glucose (Balat, Balat, \& Öz, 2008). Souza-Corrêa, Ridenti, Oliveira, Araújo and Amorim (2013), SouzaCorrêa et al. (2014) obtained conversions between $65 \%$ and $78.8 \%$ from hydrolysis of SCB treated with ozone; Travaini et al. (2013) reported $41.79 \%$ of conversion by applying Novozymes ${ }^{\circledR}$ enzymes NS50013 and NS50010, while Pereira et al. (2016) obtained $39 \%$ of conversion by using enzymes produced by Myceliophthora thermophila JCP 1-4 in SSC. However, they used different ozonolysis conditions and different enzymes and activities. Perrone et al. (2016) obtained 94\% conversion but they used a commercial enzyme and a very high enzyme load.

According to Perrone et al. (2016), it is difficult to compare the results from different studies even though the techniques are similar. Conditions of work in the laboratory and variations in experimental parameters (composition and activity of individual cellulases in the enzyme solution, time of hydrolysis, temperature, etc.) are parameters that can contribute to different results. Furthermore, the synergistic effects between cellulases are influenced by the nature of the substrate, such as chemical composition, degree of crystallinity and solubility (Yang, Yan, Chen, Lee, \& Zheng, 2007; Perrone et al., 2016). However, the results reported in the current paper show that a combination of ozone and ultrasound treatments in an alkali medium improved the saccharification when compared to BIN. Additionally, reasonable conversion could be achieved by applying self-supplied enzymes produced in a bench scale PBB. 


\section{Conclusions}

The PBB was efficient in producing cellulolytic enzymes by SSC. The enzymes obtained showed high activities and were able to carry out a high degree of saccharification of both BIN and BOU. Much higher yields of TRS were obtained from the hydrolysis of BOU, whose pretreatment increased the enzymatic digestibility and favored enzymatic conversion of cellulose into glucose. The combination of microorganism, substrate, equipment and operational conditions allowed for the production of cellulolytic enzymes with high activities. This has great potential for the successful hydrolysis of SCB in an ethanol $2 \mathrm{G}$ production chain.

\section{Acknowledgments}

The authors would like to acknowledge the Coordination for the Improvement of Higher Education Personnel (CAPES, Finance Code 001), the São Paulo Research Foundation (FAPESP) for their financial support and scholarships [grant numbers 2010/12624-0, 2011/21239-6, 2011/074535, 2013/01756-1, 2017/16482-5, 2018/009962] and the National Council for Scientific and Technological Development (CNPQ) [grant numbers 426578/2016-3 and 430786/2018-2].

\section{References}

Afonso, L. C. (2012). Produção de celulases por cultivo em estado sólido e aplicação na hidrólise do bagaço de cana-de-açúcar. Dissertação de mestrado, Universidade de São Paulo, SP, Brasil.

Badhan, A. K., Chadha, B. S., Kaur, J., Saini, H. S., \& Bhat, M. K. (2007). Production of multiple xylanilytic and cellulolytic enzymes by thermophilic fungus Myceliophthora sp. IMI 387099. Bioresource Technology, 98(3), 504-510. doi: 10.1016/j. biortech.2006.02.009

Bailey, M. J., Peterbiely, P., \& Poutanen, K. (1992). Interlaboratory testing of methods for assay of xylanase activity. Journal of Biotechnology, 23(3), 257-270. doi: 10.1016/0168-1656(92)90074-J
Balat, M., Balat, H., \& Öz, C. (2008). Progress in bioethanol processing. Progress in Energy and Combustion Science, 34(5), 551-573. doi: 10.1016/j. pecs.2007.11.001

Baruah, J., Nath, B. K., Sharma, R., Kumar, S., Deka, R. C., Baruah, D. C., \& Kalita, E. (2018). Recent trends in the pretreatment of lignocellulosic biomass for value-added products. Frontiers in Energy Research, 6, 1-19. doi: 10.3389/fenrg.2018.00141

Bi, S., Peng, L., Chen, K., \& Zhu, Z. (2016). Enhanced enzymatic saccharification of sugarcane bagasse pretreated by combining $\mathrm{O}_{2}$ and $\mathrm{NaOH}$. Bioresource Technology, 214, 692-699. doi: 10.1016/j.biortech. 2016.05 .041

Calado, V., \& Montgomery, D. (2003). Planejamento de experimentos usando o Statistic. Rio de Janeiro: E-papers Serviços Editoriais.

Canilha, L., Chandel, A. K., Milessi, T. S. S., Antunes, F. A. F., Freitas, W. L. C., Felipe, M. G. A., \& Silva, S. S. da. (2012). Bioconversion of sugarcane biomass into ethanol: an overview about composition, pretreatment methods, detoxification of hydrolysates, enzymatic saccharification, and ethanol fermentation. Journal of Biomedicine and Biotechnology, 2012, 1-15. doi: 10.1155/2012/989572

Cantwell, B. A., Sharp, P. M., Gormley, E., \& Mcconnell, D. J. (1988). Molecular cloning of bacillus b-glucanases. In J. P. Aubert, P. Beguin, \& J. Millet (Eds.), Biochemistry and genetics of cellulose degradation (pp. 181-201). San Diego: Academic Press.

Casciatori, F. P., Bück, A., Thoméo, J. C., \& Tsotsas, E. (2016). Two-phase and two-dimensional model describing heat and water transfer during solidstate fermentation within a packed-bed bioreactor. Chemical Engineering Journal, 287, 103-116. doi: 10.1016/j.cej.2015.10.108

Casciatori, F. P., Casciatori, P. A., \& Thoméo, J. C. (2013). Cellulase production in packed bed bioreactor by solid-state fermentation. Proceedings of the European Biomass Conference and Exhibition, Copenhagen, Dinamarca, 21 ${ }^{\text {st }}$. doi: 10.5071/21stEUBCE2013-3DV.1.13

Derakhti, S., Shojaosadati, S. A., Hashemi, M., \& Khajeh, K. (2012). Process parameters study of $\alpha$-amylase production in a packed-bed bioreactor under solid-state fermentation with possibility of temperature monitoring. Preparative Biochemistry and Biotechnology, 42(3), 203-216. doi: $10.1080 / 10826068.2011 .599466$ 
Fan, L. T., Gharpuray, M. M., \& Lee, Y. H. (1987). Cellulose hydrolysis biotechnology monographs. Berlin: Springer-Verlag.

Florencio, C., Badino, A. C., \& Farinas, C. S. (2017). Desafios relacionados à produção e aplicação das enzimas celulolíticas na hidrólise da biomassa lignocelulósica. Química Nova, 40(9), 1082-1093. doi: 10. 21577/0100-4042.20170104

Frassatto, P. A. C., Casciatori, F. P., Thoméo, J. C., Gomes, E., Boscolo, M., \& Silva, R. da. (2020). $\beta$-Glucosidase production by Trichoderma reesei and Thermoascus aurantiacus by solid state cultivation and application of enzymatic cocktail for saccharification of sugarcane bagasse. Biomass Conversion and Biorefinery, 1-11. doi: 10.1007/ s13399-020-00608-1

Ghildyal, N. P., Gowthaman, M. K., Raghava Rao, K. S. M. S., \& Karanth, N. G. (1994). Interaction of transport resistances with biochemical reaction in packed-bed solid-state fermentors: Effect of temperature gradients. Enzyme and Microbial Technology, 16(3), 253-257. doi: 10.1016/01410229(94) 90051-5

Ghose, T. K. (1987). Measurement of cellulase activities. Pure and Applied Chemistry, 59(2), 257-268. doi: 10.1351/pac198759020257

Kalogeris, E., Christakopoulos, P., Katapodis, P., Alexiou, A., Vlachou, S., Kekos, D., \& Macris, B. J. (2003). Production and characterization of cellulolytic enzymes from the thermophilic fungus Thermoascus aurantiacus under solid state cultivation of agricultural wastes. Process Biochemistry, 38(7), 1099-1104. doi: 10.1016/S0032-9592(02)00242-X

Leite, R. S. R., Bocchini, D. A., Martins, E. S., Silva, D., Gomes, E., \& Silva, R. da. (2007). Production of cellulolytic and hemicellulolytic enzymes from Aureobasidium pulluanson solid state fermentation. Applied Biochemistry and Biotechnology, 137(1-12), 281-288. doi: 10.1007/s12010-007-9058-y

Liu, C., Suna, R., Qin, M., Zhang, A., Rena, J., Xub, F.,... $\mathrm{Wu}$, S. (2007). Chemical modification of ultrasoundpretreated sugarcane bagasse with maleic anhydride. Industrial Crops and Products, 26(2), 212-219. doi: 10.1016/j.indcrop.2007.03.007

Lopes, A. M., Ferreira, E. X., Fº, \& Moreira, L. R. S. (2018). An update on enzymatic cocktails for lignocellulose breakdown. Journal of Applied Microbiology, 125(3), 632-645. doi: 10.1111/ jam. 13923
Manan, M. A., \& Webb, C. (2017). Design aspects of solid state fermentation as applied to microbial bioprocessing. Journal of Applied Biotechnology \& Bioengineering, 4(1), 511-532. doi: 10.15406/jabb. 2017.04.00094

Miller, G. L. (1959). Use of dinitrosalicylic acid reagent for determination of reducing sugar. Analytical Chemistry, 31(3), 426-428. doi: 10.1021/ ac60147a030

Mishima, D., Tateda, M., Ike, M., \& Fujita, M. (2006). Comparative study on chemical pretreatments to accelerate enzymatic hydrolysis of aquatic macrophyte biomass used in water purification processes. Bioresource Technology, 97(16), 21662172. doi: 10.1016/j.biortech.2005.09.029

Mitchell, D. A., Krieger, N., \& Berovic, M. (2006). Solidstate fermentation bioreactors: fundamentals, design and operation. Berlin: Springer-Verlag.

Mitchell, D. A., Pandey, A., Sangsurasak, P., \& Krieger, N. (1999). Scale-up strategies for packed bed bioreactors for solid state fermentation. Process Biochemistry, 35(1-2), 167-178. doi: 10.1016/ S0032-9592(99)00048-5

Molina, G., Contesini, F. J., Melo, C. R. R. de, Sato, H. H., \& Pastore, G. M. (2016). $\beta$-Glucosidase from Aspergillus. In V. K. Gupta (Eds.), New and future developments in microbial biotechnology and bioengineering: aspergillus system properties and applications (pp. 155-169). Amsterdã: Elsevier.

Montgomery, D. C. (2001). Design and analysis of experiments. New York: John Wiley \& Sons.

Moretti, M. M. S., Bocchini-Martins, D. A., Silva, R. da, Rodrigues, A., Sette, L. D., \& Gomes, E. (2012). Selection of thermophilic and thermotolerant fungi for the production of cellulases and xylanases under solid-state fermentation. Brazilian Journal of Microbiology, 43(3), 1062-1071. doi: 10.1590/ S1517-838 22012000300032

Oliveira Rodrigues, P. de, Pereira, J. C., Queiroz, D., Gurgel, L. V. A., Pasquini, D., \& Baffi, M. A. (2017). Synergistic action of an Aspergillus (hemi) cellulolytic consortium on sugarcane bagasse saccharification. Industrial Crops and Products, 109(1), 173-181. doi: 10.1016/j.indcrop.2017.08.031

Pereira, J. C., Travaini, R., Marques, N. P., BoladoRodríguez, S., \& Martins, D. A. B. (2016). Saccharification of ozonated sugarcane bagasse using enzymes from Myceliophthora thermophila JCP 1-4 for sugars release and etanol production. Bioresource Technology, 204, 122-129. doi: 10.1016/j. biortech.2015.12.064 
Perez, C. L., Casciatori, F. P., \& Thoméo, J. C. (2019). Strategies for scaling-up packed-bed bioreactors for solid-state fermentation: the case of cellulolytic enzymes production by a thermophilic fungus. Chemical Engineering Journal, 361, 1142-1151. doi: 10.1016/j.cej.2018.12.169

Perrone, O. M., Colombari, F. M., Rossi, J. S., Moretti, M. M. S., Bordignon, S. E., Nunes, C. C. C., Silva, R. da. (2016). Ozonolysis combined with ultrasound as a pretreatment of sugarcane bagasse: effect on the enzymatic saccharification and the physical and chemical characteristics of the substrate. Bioresource Technology, 218, 69-76. doi: 10.1016/j. biortech.2016.06.072

Plácido, J., \& Capareda, S. (2014). Analysis of alkali ultrasonication pretreatment in bioethanol production from cotton gin trash using FT-IR spectroscopy and principal component analysis. Bioresources and Bioprocessing, 1(23), 1-9. doi: 10.1186/s40643-0140023-7

Sandgren, M., Stahlberg, J., \& Mitchinson, C. (2005). Structural and biochemical studies of GH family 12 cellulases: improved thermal stability, and ligand complexes. Progress in Biophysics and Molecular Biology, 89(3), 246-291. doi: 10.1016/j. pbiomolbio.2004.11.002

Silva, R. da, Lago, E. S., Merheb, C. W., Macchione, M. M., \& Park, Y. K. (2005). Production of xylanase and CMCase on solid state fermentation in different residues by Thermoascus aurantiacus Miehe. Brazilian Journal of Microbiology, 36(3), 235-241. doi: 10.1590/S1517-83822005000300006

Sluiter, A., Hames, B., Ruiz, R. O., Scarlata, C., Sluiter, J., Templeton, D., \& Crocker, D. (2008). Determination of structural carbohydrates and lignin in biomass. Technical Report NREL, TP-510-42618). Biomass Anal. Golden, CO: National Renewable Energy Laboratory Technol. (Recuperado de https://www. nrel.gov/biomass/pdfs/42618.pdf

Soni, R., Nazir, A., Chadha B. S., \& Saini, H. S. (2008). Novel sources of fungal cellulases for efficient deinking of composite paper wast. Bioresources, 3(1), 234-246.
Souza-Corrêa, J. A., Oliveira, C., Nascimento, V. M., Wolf, L. D., Gómez, E. O., Rocha, G. J. M., \& Amorim, J. (2014). Atmospheric pressure plasma pretreatment of sugarcane bagasse: the influence of biomass particle size in the ozonation process. Applied Biochemistry and Biotechnology, 172(3), 1663-1672. doi: 10.1007/s12010-013-0609-0

Souza-Corrêa, J. A., Ridenti, M. A., Oliveira, C., Araújo, S. R., \& Amorim, J. (2013). Decomposition of lignin from sugar cane bagasse during ozonation process monitored by optical and mass spectrometries. The Journal of Physical Chemistry, 117(11), 3110-3119. doi: 10.1021/jp3121879

Sun, J. X., Sun, R., Sun, X. F., \& Su, Y. (2004). Fractional and physico-chemical characterization of hemicelluloses from ultrasonic irradiated sugarcane bagasse. Carbohydrate Research, 339(2), 291-300. doi: 10.1016/j.carres.2003.10.027

Travaini, R., Otero, M. D. M., Coca, M., Silva, R. da, \& Bolado, S. (2013). Sugarcane bagasse ozonolysis pretreatment: effect on enzymatic digestibility and inhibitory compound formation. Bioresource Technology, 133, 332-339. doi: 10.1016/j. biortech.2013.01.133

Velmurugan, R., \& Muthukumar, K. (2011). Utilization of sugarcane bagasse for bioethanol production: sono-assisted acid hydrolysis approach. Bioresource Technology, 102(14), 7119-7123. doi: 10.1016/j. biortech.2011.04.045

Yang, H., Yan, R., Chen, H., Lee, D. H., \& Zheng, C. (2007). Characteristics of hemicellulose, cellulose and lignin pyrolysis. Fuel, 86(12-13), 1781-1788. doi: 10.1016/j.fuel.2006.12.013

Zanelato, A. I., Shiota, V. M., Gomes, E., \& Thoméo, J. C. (2012). Endoglucanase production with the newly isolated Myceliophthora sp. I-1D3b in a packed bed solid state fermentor. Brazilian Journal of Microbiology, 43(4), 1536-1544. doi: 10.1590/ S1517-83822012000400038 
